\title{
Phytochemical Identification and Anti-Oxidant Study of Essential Oil Constituents of Ocimum basilicum L. Growing in Iraq
}

\author{
Abed S. Ahmed ${ }^{1, *}$, Abo Khthr M. Fanokh ${ }^{2}$, Mahood A. Mahdi ${ }^{3}$
}

Abed S. Ahmed ${ }^{1, *}$, Abo Khthr M. Fanokh' ${ }^{2}$, Mahood A. Mahdi $^{3}$

'Natural Products of Pharmacognosy Department, Pharmacy College, University of Kerbala, Kerbala, IRAQ.

${ }^{2}$ Master in Pharmaceutical Chemistry

Department, Pharmacy College, University of Kerbala, Kerbala, IRAQ.

${ }^{3}$ Full Professor Pharmaceutical Chemistry

Department, Pharmacy College, University

of Kerbala, Kerbala, IRAQ.

Correspondence

\section{Salam Ahmed Abed}

Pharmacognosy Department, Pharmacy College, University of Kerbala, Kerbala, IRAQ.

Phone no: 009647713458879

E-mail: salam.a@uokerbala.edu.iq

History

- Submission Date: 05-12-2018;

- Review completed: 09-04-2019.

- Accepted Date: 24-04-2019.

DOI : 10.5530/pj.2019.11.115

Article Available online

http://www.phcogj.com/v11/i4

Copyright

(C) 2019 Phcogj.Com. This is an openaccess article distributed under the terms of the Creative Commons Attribution 4.0 International license.

\section{ABSTRACT}

Introduction: Essential oil of Iraqi growing Ocimum basilicum (Thia basil) was studied for their chemical components investigation and antioxidant activity. Methods: Essential oils of leaves and stems of Ocimum basilicum were collected using hydrodistillation by Clevenger apparatus. Components of the collected essential oils were examined by the techniques such as Gas chromatography and Gas chromatography-mass spectrometry. Results: The analysis showed that the major components of essential oils were linalool (48.69\%), 1,8-cineole $(14.00 \%)$, trans- $\alpha$-bergamotene $(8.23 \%)$ and eugenol $(6.64 \%)$. The antioxidant investigation was achieved using 1,1-diphenyl-2-picrylhydrazyl (DPPH) as a radical scavenger and bleaching of $\beta$-carotene/linoleic assay. The essential oil displayed strong inhibition with $110.8 \%$ against autoxidation of linoleic acid, while the scavenging of DPPH radical gave a value of $\mathrm{IC}_{50} 145.35$ $\mu \mathrm{g} / \mathrm{mL}$. Conclusion: The results signify that essential oils of $O$. Basilicum could be used for pharmaceutical studies and preservative in the food industry. This is the first study of the essential components of new cultivate of Thai basil in Iraq.

Key words: $O$. basilicum, Thai basil, $\beta$-carotene, Linalool, DPPH.

\section{INTRODUCTION}

Ocimum basilicum L (English name: thai basil) is a member of Lamiaceae family. It is an important species of genus Ocimum, which is a group of 150 kinds of aromatic plants that can distributed in a variety parts of the tropic and warm regions. ${ }^{1}$ It is present in India, Malaysia, Australia and some Arab countries. ${ }^{1,2}$ Ocimum basilicum $(\mathrm{Ob})$ is used traditionally for longevity and healthy life purposes due to its revitalizing and tonic effects. flower and leaves are used as aromatic, carminative, antispasmodic and galactogogue. Also they used in folk medicine for the management of fever, nausea, migraine, poor digestion, abdominal cramps, gastroenteritis, insomnia, chronic diarrhea exhaustion and dysentery. ${ }^{3} O$. basilicum, sweet basil, was used in traditional medicine of Yemen for the treatment of different ailments: abdominal pain, gastro-enteritis, diarrhea and dysentery. In Sultanate of Oman and Saudi Arabia, leaves juice or crushed leaves juice were used in the management of injuries, acne and vitiligo. It is also used as a antiperspirant, which is considering as an aphrodisiac for men. ${ }^{4}$ The plant has important vitamins such as $\mathrm{A}$ and $\mathrm{C}$ and many metals like $\mathrm{Ca}^{2+}, \mathrm{Zn}^{2+}, \mathrm{Na}^{1+}, \mathrm{Mg}^{2+}$ and $\mathrm{Fe}^{2+}$. The essential oil of Ocimum species. gained wide importance, because of their many bioactivities. It is used as antiseptic, antihistaminic, antimicrobial, anti-inflammatory, antihelimenthic, antioxidant, immunomodulatory effect, anti-depressant, anti-diabetic, antihyperlipidemia, hepatoprotective, neuroprotective effect and cardio-protective and anti-cancer activity. ${ }^{6,7}$

In terms of chemical composition of essential oils, O. basilicum characterized by two or three major components (20-70\%) of volatile oil and other components present as minor components. It is composed of major constituents such as linalool, eugenol, methyl eugenol and methyl chavicol. However, these major constituents have been reported to occur in different percentages according to geographical locations (Table 1$){ }^{6}$

Ocimum basilicum is cultivated in Iraq (Figure 1) and it is called "Reyhan". Fresh and dried leaves and stems are widely used in kitchen as an example in vegetable salads, meat and soups. In folk medicine, it is used antispasmodic and carminative. However, information about the essential oil components of Ocimum basilicum that was growing in Iraq is not

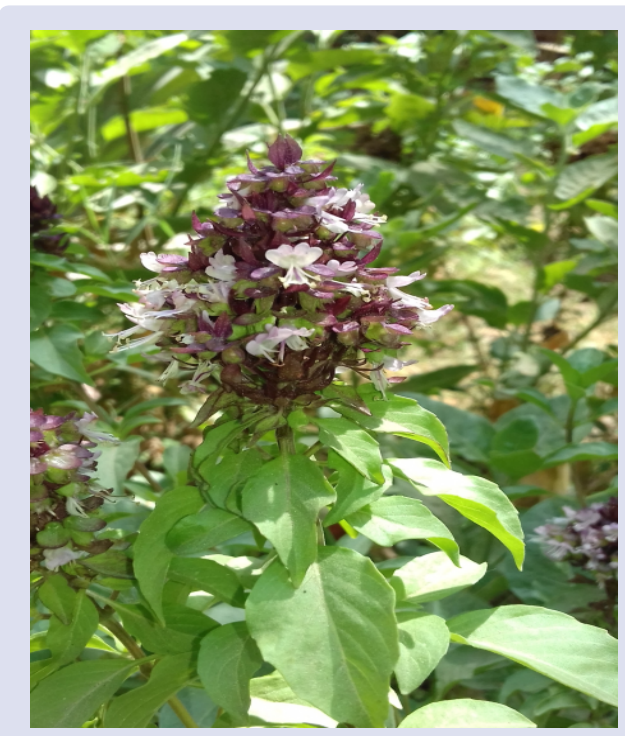

Figure 1: Ocimum basilicum (Iraqi growing).

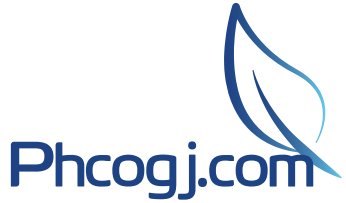

Cite this article: Ahmed AS, Fanokh AKM, Mahdi MA. Phytochemical Identification and Anti-Oxidant Study of Essential Oil Constituents of Ocimum basilicum L. Growing in Iraq Pharmacog J. 2019;11(4):724-9. 
Table 1: The effect of geographical location of the chemical component of $O$. basilicum essential oil.

\begin{tabular}{|c|c|}
\hline Location & Percentage of major constituents $(\%)^{8}$ \\
\hline Turkey & $\begin{array}{l}\text { Linalool (45.7), Eugenol (13.4), methyl eugenol (9.57) } \\
\text { and Funchyl alcohol (3.64) }\end{array}$ \\
\hline Sudan (Um-Ruaba) & Methyl chavicol (70.0), Linalool (25), Eugenol (5.0) \\
\hline Pakistan & $\begin{array}{l}\text { Methyl chavicol (87.3), Linalool (5.4), methyl eugenol } \\
\text { (1.5), } \beta \text {-Caryophyllene (2.4) } \\
\text { a-Pinene (1.00) }\end{array}$ \\
\hline Western of Cameroon & Linalool (50.8), Limonene (10.4) \\
\hline Guinea & $\begin{array}{l}\text { Linalool (69.0), Eugenol (10.0), } \\
\text { (E)- } \alpha \text {-Bergamotene (3.0) }\end{array}$ \\
\hline Egypt & Linalool (44.18), 1,8-Cineole (13.65), Eugenol (8.59) \\
\hline India (Attarakhand) & $\begin{array}{l}\text { Methyl chavicol (70.04), Linalyl acetate (22.54), } \\
\text { camphene }(7.32) \text {. }\end{array}$ \\
\hline European Basil & Linalool (53.0), Methyl chavicol (29.0) \\
\hline Togo (Lome) & Estragole (85.5), Linalool (1.71) \\
\hline
\end{tabular}

available. Therefore, it was worthy to undertake such investigation by isolations of the essential oils of the leaves and stem of Ocimum basilicum $L$ which cultivated in Iraq. The oil, extensively identifies using GC and GC-MS. Then, the anti-oxidant action of the essential oil was evaluated using bleaching of $\beta$-carotene and DPPH scavenging assay.

\section{EXPERIMENTAL}

\section{Plant material}

Leaves and stems were collected during October / 2010 from the garden of the medicinal plants of the Kerbala University in Iraq. The sample was identified by the Iraqi National Herbarium in Abu-Graib. The drying was under shade at room temperature. Then the plants' leaves and stems were ground by blender and the total weight of the powder was $300 \mathrm{gm}$.

\section{Hydrodistillation}

The plant material of $O$. basilicum was submitted to hydrodistillation for $8 \mathrm{~h}$, to Clevenger system. Then, the oils were extracted from the water layer with diethyl ether and dried over sodium sulfate anhydrous. These oil samples are kept in the refrigerator $(2-4)^{\circ} \mathrm{C}$ before the submitting for the chemical analysis.

\section{Gas chromatography (GC)}

Oil constituents were analyzed by Gas Chromatography (HewlettPackard HP-6890) with FID and setted with Ultra-1 column (100\% polymethylsiloxanes) $(25 \mathrm{~m} \times 0.33 \mu \mathrm{m}$ thickness of film $\times 0.20 \mathrm{~mm}$ i.d.). The temperature of the column was programmed from $50^{\circ} \mathrm{C}$ for 5 min to $300^{\circ} \mathrm{C}$ for $5 \mathrm{~min}$ at rate $4^{\circ} \mathrm{C} / \mathrm{min}$. The carrier gas was Helium with a flow rate $1 \mathrm{ml} / \mathrm{min}$. Diethyl ether was used as a solvent for sampling. The sample $(0.1 \mu \mathrm{L})$ was prepared by diluting $1 / 100(\mathrm{v} / \mathrm{v})$. On the other hand, standard hydrocarbons $\left(\mathrm{C}_{9}-\mathrm{C}_{20}\right)$ were used as reference in the Kovats Index of $O$. basilicum oil.

\section{Gas chromatography- mass spectroscopy (GC-MS)}

The analyses in GC-MS carried out using GC (Hewlett Packard model 5890 A) and MS (Hewlett Packard model 5989 A). The GC was prepared with an Ultr- 1 column $(25 \mathrm{~m} \times 0.33 \mu \mathrm{m}$ thickness of the film $\times 0.20 \mathrm{~mm}$ i.d.). The oven temperature was $50^{\circ} \mathrm{C}$ for $(5 \mathrm{~min})$ at the beginning and it was increased to $280^{\circ} \mathrm{C}$ at a rate $\left(8^{\circ} \mathrm{C} / \mathrm{min}\right)$ for $(8 \mathrm{~min})$. The solvent was dimethyl ether for dissolving and preparing the sample. Helium was a carrier gas with flow rate $1 \mathrm{ml} / \mathrm{min}$.

\section{Measurement of antioxidant activity using DPPH}

The essential oil capacity of $O$. basilicum to scavenge free radicals was evaluated by the ability to capture the radical of DPPH. ${ }^{8}$ First, a stock solution $(1000 \mu \mathrm{g} / \mathrm{mL})$ was prepared in methanol and then a series of a diluted sample in methanol were prepared to yield a sample (200 $\mu \mathrm{L}, 15.63-1000 \mu \mathrm{g} / \mathrm{mL})$ in disposable cuvettes. Then DPPH $(3800 \mu \mathrm{L}$, $1000 \mu \mathrm{g} / \mathrm{mL}$ ) in methanol was added to each cuvette. The reaction was kept over $30 \mathrm{~min}$ in the dark at room temperature. The absorbance was measured for each sample at $(\lambda \max =517 \mathrm{~nm})$. The absorbance measurement of the negative control (DPPH and methanol) was at (0 min). In this test, the increment in the absorbance of the sample is associated with the lowest scavenging activity. The inhibition percentage (I\%) of DPPH radical was measured using the subsequent formula:

$$
\mathrm{I} \%=\left[\left(\mathrm{Abs}_{\text {blank }}-\mathrm{Abs}_{\text {sample }}\right) / \mathrm{Abs}_{\text {blank }}\right] \times 100
$$

$\mathrm{Abs}_{\text {blank }}=$ Control absorbance of the: (DPPH and methanol).

$\mathrm{Abs}_{\text {sample }_{\text {e }}}=$ Extract or Standard absorbance: (BHT).

\section{Bleaching assay by Beta-carotene/linoleic acid}

The bleaching assay using $\beta$-carotene/ linoleic acid used to evaluate the inhibition ability of chemical components by $\beta$-carotene oxidation in the presence of $\left(\mathrm{O}_{2}\right)$. The procedure was achieved as detailed in the literature, with slight modification. ${ }^{9} \beta$-Carotene was mixed with linoleic acid by dissolving $\beta$ - carotene $(0.5 \mathrm{mg})$ in chloroform $(1 \mathrm{~mL})$ and linoleic acid $(25 \mu \mathrm{L})$ and Tween $(200 \mathrm{mg})$. Then, the chloroform was vaporized under vacuum. Oxygenated D. W $(100 \mathrm{ml})$ was consequently added and diverse gently to obtain a clear yellow emulsion. $O . b$ oil and BHT were dissolved individually in methanol $(2 \mathrm{mg} / \mathrm{ml})$ and $(350$ $\mu \mathrm{L})$ of each were added to the yellowish emulsion $(2.5 \mathrm{~mL})$ in test tube and mixed carefully. The mixture and the blank were incubated in a water bath for $(2 \mathrm{hrs})$ at $50^{\circ} \mathrm{C}$. The absorbance was measured at $470 \mathrm{~nm}$. Percent of Inhibitions (I\%) of the samples were measured according to the subsequent equation:

$$
\mathrm{I} \%=\left[\mathrm{A}_{\beta \text {-carotene after } 2 \mathrm{~h}} / \mathrm{A}_{\text {initial } \beta \text {-carotene }}\right] \times 100
$$

\section{RESULTS AND DISCUSSION}

The essential oil of $O$. basilicum was collected by hydrodistillation as pale yellowish $(0.40 \mathrm{~g}, 0.40 \%)$. The chemical components were investigated by GC and GC-MS. The identification of essential oil components was achieved by comparing

their Kovat's indices with the reported values of authentic compounds in the literature. ${ }^{10}$ The results of GC and GC-Ms analysis displayed that the major components of essential oil of O. basilicum from Iraq were linalool $(48.69 \%), 1,8$-cineole $(14.00 \%)$, trans- $\alpha$-bergamotene (8.23\%) and eugenol (6.64\%) (Figure 2). Moreover, it has shown that there are other minor components of O. basilicum which were represented in (Table 2).<smiles>C=CC(C)(O)CCC=C(C)C</smiles><smiles>CC12CCC(CC1)C(C)(C)O2</smiles>

linalool

1,8 -cineole<smiles>CC(C)=CCC[C@]1(C)CCC=C(C)C1</smiles>

trans-a-bergamotene

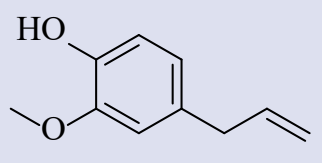
eugenol

Figure 2: The structure of major components of O.basilicum essential oil. 
Many studies have reported the effect of cultivation site on the components of the essential oil of O. basilicum. For example, methyl chavicol presents as the highest main content in the Nigerian $O$. basilicum (60.30\%). ${ }^{11}$ where it was considered as a main component for Um-Ruaba and Pakistan in a percent about $70 \%$ and $87.30 \%$, respectively. ${ }^{6}$ Moreover, the site of cultivation has an effect not only on the percent of the composition but also on the type of the main constituents. Linalool, for an instant, is the major component in $O$. basilicum essential oils from North-eastern Brazil (42.5\%), ${ }^{7}$ Greek $(43.1 \%),{ }^{12}$ Egypt $(44.18 \%)$ and Turkey $(45.70 \%) .{ }^{6}$ More interestingly, the essential oil of Iraqi grown O. basilicum was showed, that linalool was the main component (48.69\%, Table 2). The major differences in the contents of essential oil were attributed to the change in the location and climate differences. ${ }^{13}$

Linalool is an aliphatic compound that has three allylic hydrogens. These threes can participate potentially in antioxidant effect. The extract of essential oil has also phenol and terpene components which are also having antioxidant effect. The antioxidant action was examined by $\beta$-carotene-linoleic acid bleaching assay and DPPH scavenging assay. The results of the scavenging activity are reported in Table 3.

In terms of DPPH scavenging assay, it bases on the capturing free radical DPPH by an antioxidant (HA). The ability of HA as an antioxidant was determined by measuring the decreasing in the absorbance of the purple color of the DPPH. ${ }^{9} \mathrm{DPPH}$ radical received hydrogen radical from an antioxidant $\mathrm{HA}$ and as illustrated in Figure 3.
It has been reported that essential oil of O. basilicum showed antioxidant activity, which was relatively more than a quarter the antioxidant activity of ascorbic acid. In terms of numbers, the essential oil exhibits $\mathrm{IC}_{50} 145.35 \mu \mathrm{g} / \mathrm{mL}$, while the standard ascorbic acid shows a high scavenging potency for DPPH radical with $\mathrm{IC}_{50} 35.1 \mu \mathrm{g} / \mathrm{mL}$. This finding indicates that the activity of antioxidant from major component linalool; as well as, the other minor components of the volatile oil.

Moreover, $\beta$-carotene-linoleic acid bleaching assay exhibited that the volatile oil has a potential scavenging efficacy. The potency of O. basilicum was very strong $(110.8 \%)$ and it is equivalent to the standard BTH (110.7\%). This activity was attributed to the presences of antioxidant components of the essential oil such as linalool.

According to the GC-MS analysis of Iraqi O. basilicum, linalool is the major component of essential oil. The result of $\beta$-carotene-linoleic acid bleaching assay showed that essential oils of $O$. basilicum exhibited a high antioxidant potency (110.8\%). Linalool (HA) possesses high potency as antioxidant ${ }^{13}$ due the presence of allylic hydrogens (Figure 4). In fact, the free peroxy linoleic radical (LOO•) has a good opportunity to abstract allylic $\mathrm{H}$ of linalool, which then converts to (LOOH). This could explain the strong inhibitory activity of lipid peroxidation of essential oil as a result of the high content of linalool and other major components such as trans- $\alpha$-bergamotene $(8.23 \%)$ and eugenol (6.64\%), which are all having allylic hydrogen in their structures (Figure 4). While, in the absence of the anti-oxidant (HA), linoleic acid undergoes rapid peroxidation and produce peroxy linoleic

Table 2: The components of essential oil of $O$. basilicum growing in Iraq.

\begin{tabular}{|c|c|c|c|c|c|}
\hline No. & Compound & $\mathrm{Rt}_{\mathrm{x}}$ & Area\% & $\mathrm{KI}$ & $\mathrm{KI}_{\mathrm{L}}$ \\
\hline 1 & $\beta$-Pinene & 10.41 & 0.86 & 949 & 949 \\
\hline 2 & 1,8-cineole & 11.748 & 14.00 & 1014 & 1016 \\
\hline 3 & p-cymene & 11.836 & 0.49 & 1016 & 1015 \\
\hline 4 & (E)-B-ocimene & 13.036 & 0.32 & 1047 & 1048 \\
\hline 5 & $\gamma$-terpinene & 13.64 & 0.55 & 1061.90 & 1060 \\
\hline 6 & Linalool & 14.806 & 48.69 & 1087.94 & 1086 \\
\hline 7 & terpinen-4-ol & 17.523 & 3.79 & 1157.03 & 1155 \\
\hline 8 & a-terpineol & 18.023 & 1.71 & 1169.32 & 1173 \\
\hline 9 & exo-fenchyl acetate & 19.276 & 0.56 & 1198.69 & 1214 \\
\hline 10 & Linalool propanoate & 24.395 & 1.2 & 1340.84 & 1337 \\
\hline 11 & exo-2-hydroxy cineole acetae & 24.597 & 0.25 & 1346.71 & 1354 \\
\hline 12 & eugenol & 25.264 & 6.46 & 1365.75 & 1368 \\
\hline 13 & Geratnyl acetate & 25.468 & 0.75 & 1371.48 & 1365 \\
\hline 14 & a-copaene & 25.476 & 0.23 & 1371.70 & 1376 \\
\hline 15 & $\beta$-elemene & 25.748 & 1.13 & 1379.26 & 1375 \\
\hline 16 & Z-caryophyllene & 26.601 & 2.37 & 1402.99 & 1404 \\
\hline 17 & Trans-caryophyllene & 27.367 & 0.58 & 1427.46 & 1419 \\
\hline 18 & a-trans-bergamotene & 27.507 & 8.23 & 1431.85 & 1434 \\
\hline 19 & $\beta$-humulene & 27.712 & 0.24 & 1438.25 & 1438 \\
\hline 20 & epi-bicyclosesquiphellandrene & 27.97 & 0.33 & 1446.24 & 1438 \\
\hline 21 & Germacrene-D & 29.4 & 1.83 & 1489.22 & 1485 \\
\hline 22 & Germacrene-A & 30.011 & 0.23 & 1508.00 & 1508 \\
\hline 23 & Germacrene-B & 31.38 & 0.94 & 1552.27 & 1559 \\
\hline
\end{tabular}

$\mathrm{KI}$ is Kovats index from our experimental.

$\mathrm{KI}_{\mathrm{L}}$ is Kovats index obtained from literature by Adams. ${ }^{10}$

Table 3: $\beta$-Carotene-linoleic acid bleaching and the scavenging activity on free radical DPPH of 0 . basilicum volatile oil.

\begin{tabular}{|c|c|c|}
\hline Samples & $\beta$-carotene-linoleic acid & Scavenging DPPH IC ${ }_{50}(\mu \mathrm{g} / \mathrm{mL})$ \\
\hline O.basilicum volatile oil & $110.8 \pm 0.02$ & 145.35 \\
\hline BHT & $110.7 \pm 0.01$ & - \\
\hline $\mathrm{AA}$ & - & 35.135 \\
\hline
\end{tabular}

$\mathrm{AA}=$ Ascorbic Acid; BHT = Butylatedhydroxytoluene 


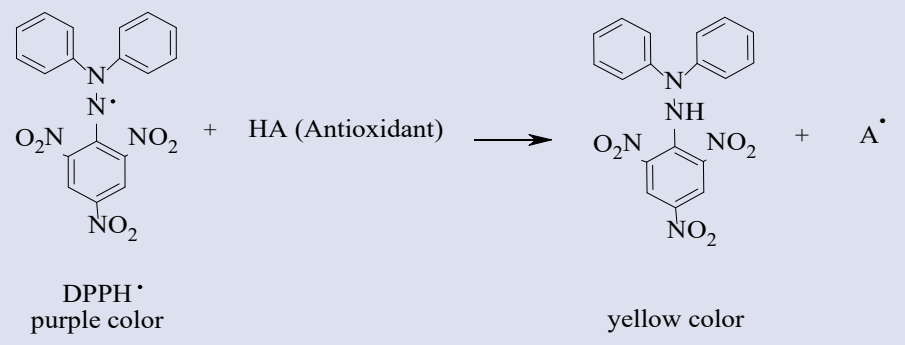

Figure 3: Quenching of the DPPH free radical by an antioxidant (HA).

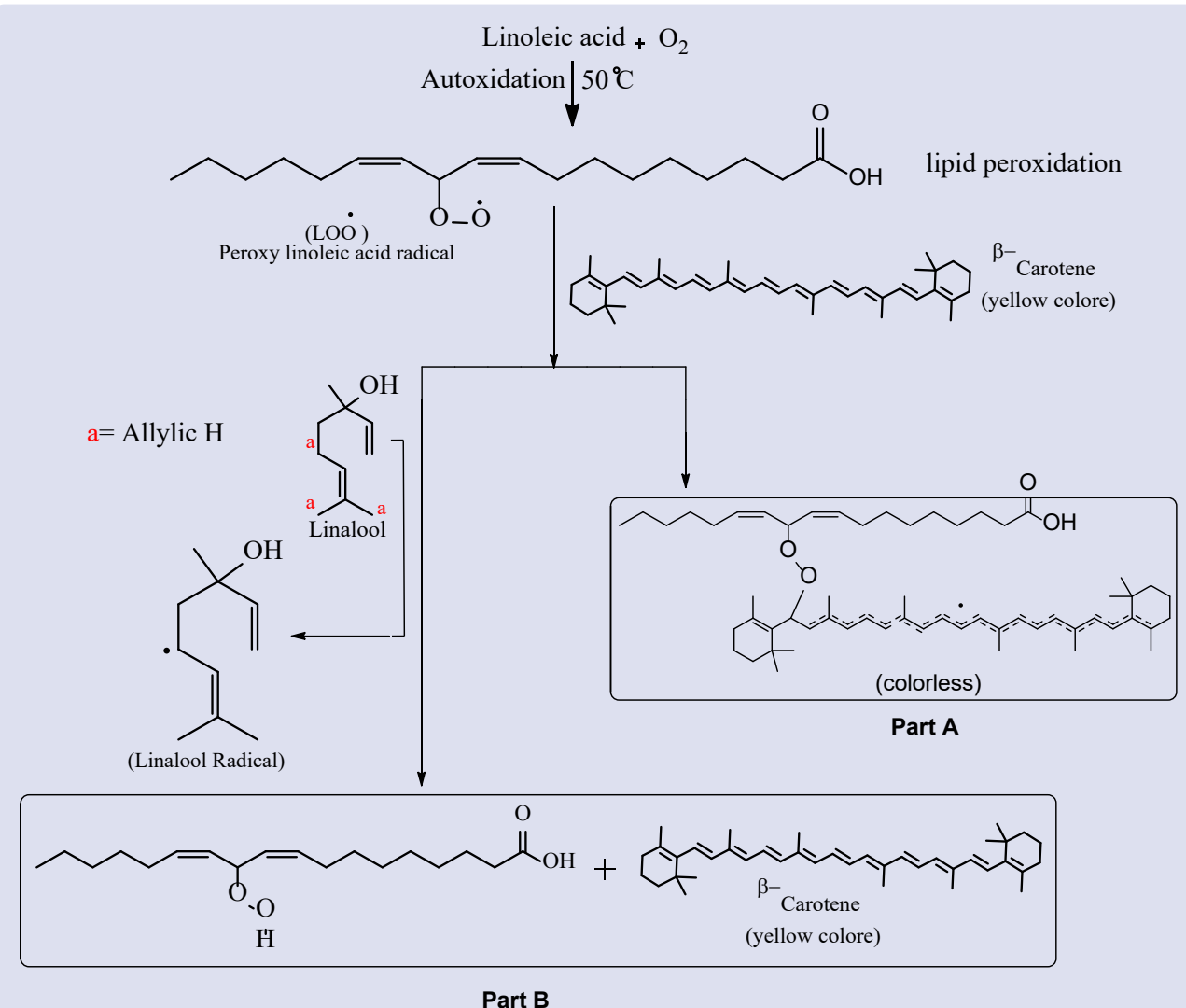

Figure 4: The suggested hyperoxidation of $\beta$-carotene-linoleic acid by atmospheric oxygen in the absence/ presence of an anti-oxidant linalool.

acid radical (LOO•) which then attacks $\beta$-carotene molecules and led to discoloration of $\beta$-carotene. The discoloration is due to the lost of the double bond from the conjugate system as explained in (Figure 4).

\section{CONCLUSION}

The chemical composition of $O$. basilicum is changing according to the geographical location. Iraqi growing O.basilicum has linalool as the highest constituent of the essential oil. The antioxidant activity was evaluated through $\beta$-carotene-linoleic acid and DPPH assays. In $\beta$-carotene-linoleic acid assay, the essential oil showed antioxidant activity equivalent to what was reported for BHT. Whereas it is about one quarter of ascorbic acid in DPPH assay. Linalool and other main components contain an allylic hydrogen, which can easily abstract by (LOO) in $\beta$-carotene-linoleic acid and exhibition the antioxidant activity.

\section{DEDICATION}

S. A. A. dedicates this study to Prof. Dr. Hasnah Mohd Sirat of Universiti Teknologi, Malaysia.

\section{ACKNOWLEDGEMENT}

The authors would like to thank Kerbala University in Iraq for partial financial support.

\section{CONFLICTS OF INTEREST}

Authors declare that there is no conflicts of interest.

\section{ABBREVIATIONS}

DPPH: 1,1-diphenyl-2-picrylhydrazyl; KI: Kovats Index; AA: Ascorbic Acid; BHT: Butylatedhydroxytoluene; $\mathrm{IC}_{50}$ : Inhibitory Concentration; $\mu \mathrm{g} / \mathrm{ml}$ : Microgram per Mililiter; ${ }^{\circ} \mathrm{C}$ : Degree Celsius; $\mathrm{mg} / \mathrm{mL}$ : Milligram per Mililiter; $\mu \mathrm{L}$ : Microliter; min: Minutes; $\mu \mathrm{L}$ : Mililiter; HA: Linalool; LOO•: Peroxy Linoleic Radical.

\section{REFERENCES}

1. Tchatchouang $S$, Beng $V$, Kuete $V$. Antiemetic African medicinal spices and vegetables. Medicinal Spices and Vegetables from Africa: Elsevier. 2017:299313 
2. Chenni M, El Abed D, Rakotomanomana N, Fernandez X, Chemat F. Comparative study of essential oils extracted from Egyptian basil leaves (Ocimum basilicum L.) using hydro-distillation and solvent-free microwave extraction. Molecules. 2016;21(1):113

3. Kaya I, Yigit N, Benli M. Antimicrobial activity of various extracts of Ocimum basilicum $L$. and observation of the inhibition effect on bacterial cells by use of scanning electron microscopy. African Journal of Traditional, Complementary and Alternative Medicines. 2008;5(4):363-9.

4. Ali N, Setzerb WN. Pharmacological activities of basil oil a review. Recent Progress in Medicinal Plants. 2013;37:286-307.

5. Pachkore G, Dhale D. Phytochemicals, vitamins and mineral s content of three ocimum species. IJSID. 2012;2:201-7.

6. Pandey AK, Singh P, Tripathi NN. Chemistry and bioactivities of essential oils of some Ocimum species: an overview. Asian Pacific Journal of Tropical Biomedicine. 2014;4(9):682-94.

7. de Vasconcelos Silva MG, de Abreu Matos FJ, Lacerda Machado MI, Craveiro AA. Essential oils of Ocimum basilicum L., O. basilicum. var. minimum L. and O. basilicum. var. purpurascens Benth. grown in north-eastern Brazil. Flavour and Fragrance Journal. 2003;18(1):13-4.
8. Salleh WM, Ahmad F, Yen KH, Zulkifli RM. Chemical composition and biological activities of essential oil of Beilschmiedia pulverulenta. Pharmaceutical Biology. 2016;54(2):322-30

9. Bamoniri A, Ebrahimabadi AH, Mazoochi A, Behpour M, Kashi FJ, Batooli H. Antioxidant and antimicrobial activity evaluation and essential oil analysis of Semenovia tragioides Boiss. from Iran. Food Chemistry. 2010;122(3):553-8.

10. Adams RP. Identification of essential oil components by gas chromatography/ mass spectrometry. Allured Publishing Corporation; 2007.

11. Kasali AA, Eshilokun AO, Adeola S, Winterhalter $P$, Knapp $H$, Bonnlander B, et al. Volatile oil composition of new chemotype of Ocimum basilicum L. from Nigeria. Flavour and Fragrance Journal. 2005;20(1):45-7.

12. Ntalli NG, Ferrari F, Giannakou I, Menkissoglu-Spiroudi U. Phytochemistry and nematicidal activity of the essential oils from 8 Greek Lamiaceae aromatic plants and 13 terpene components. Journal of Agricultural and Food Chemistry. 2010;58(13):7856-63.

13. Seol G-H, Kang P, Lee HS, Seol GH. Antioxidant activity of linalool in patients with carpal tunnel syndrome. BMC Neurology. 2016;16(1):17.

\section{GRAPHICAL ABSTRACT}

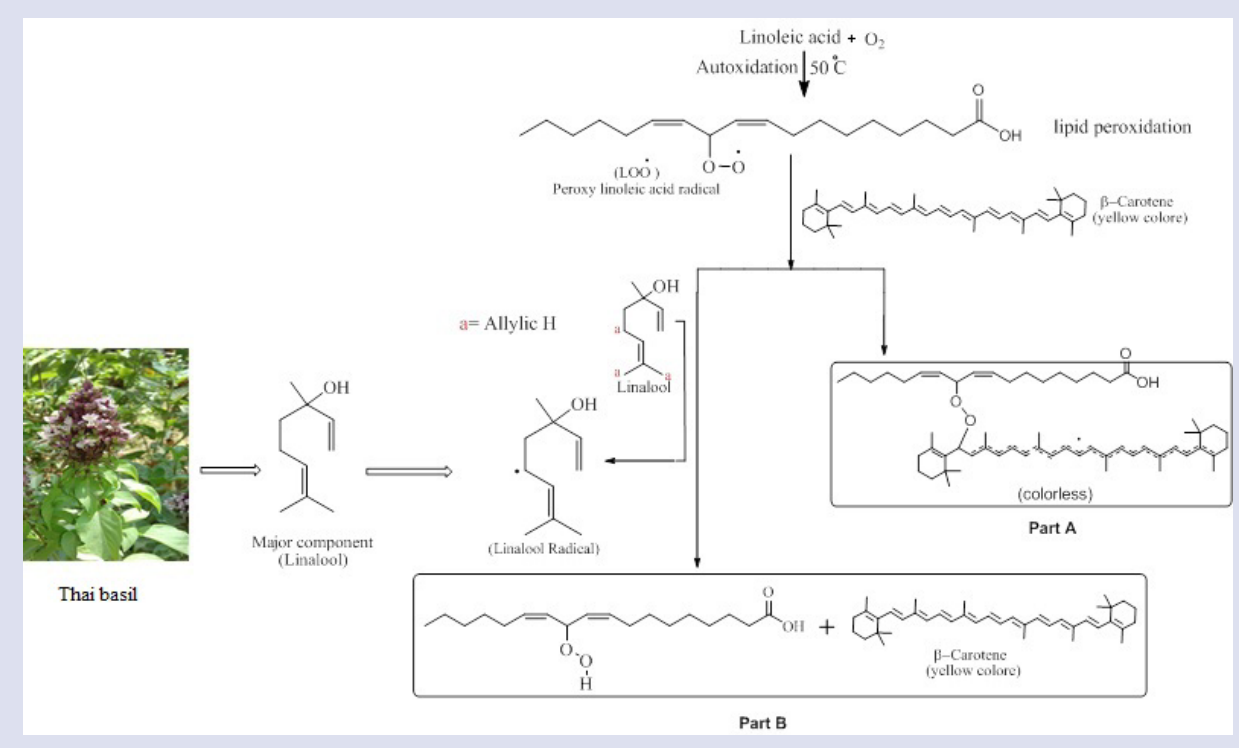

\section{SUMMARY}

Essential oil of Iraqi growing Ocimum basilicum was studied for chemical investigation and antioxidant activity. The analysis showed that the major components of essential oils were Linalool (48.69\%), 1,8-cineole (14.00\%), trans- $\alpha$-bergamotene $(8.23 \%)$ and eugenol (6.64\%). The essential oil displayed strong inhibition with $110.8 \%$ against autoxidation of linoleic acid, while the scavenging of DPPH radical gave a value of $\mathrm{IC}_{50} 145.35 \mu \mathrm{g} / \mathrm{mL}$. This is the first study of the essential components of new cultivate of Thai basil in Iraq.

\section{ABOUT AUTHORS}

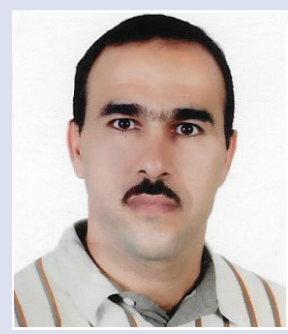

Salam Ahmed Abed is specialized in Natural Product and Organic Chemistry. Ph.D. degree in Natural Product Chemistry, from Universiti Teknologi Malaysia (UTM). Currently, works at Pharmacognosy Department/ Pharmacy College, University of Kerbala. 


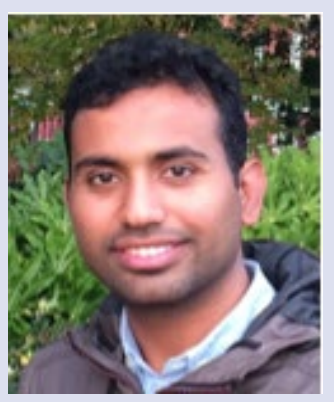

Abo Khthr M. Fanokh is a Lecturer in Pharmaceutical Chemistry Department, MSc Drug Chemistry/ Newcastle University/ UK and his research areas of interest are studying the antioxidant effect of natural product, molecular docking, and organic synthesis of bioactive molecules.

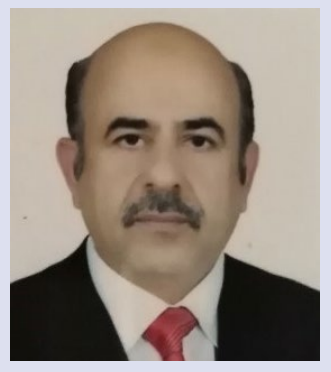

Prof. Dr. Abdulbari Mahdi Mahood is an head department of Pharmaceutical Chemistry, works in Analytical chemistry-Chromatography-HPLC and Gas Chromatography, TLC and flow-injection spectrometer-Uv-Visible, FT-IR and Atomic absorption.

Cite this article: Ahmed AS, Fanokh AKM, Mahdi MA. Phytochemical Identification and Anti-Oxidant Study of Essential Oil Constituents of Ocimum basilicum L. Growing in Iraq. Pharmacog J. 2019;11(4):724-9. 